\title{
Abstract \\ Changes in Gene Expression of Metalloproteinases-2 and -9 and Their Inhibitors TIMP2 and TIMP3 in Human Glioma Cells Exposed to Low Levels of Fluoride ${ }^{\dagger}$
}

\author{
Magdalena Nowak *, Marta Skórka-Majewicz *(i) and Wojciech Żwierełło *(i) \\ Department of Medical Chemistry, Pomeranian Medical University, Powst. Wlkp. 72, 70-111 Szczecin, Poland \\ * Correspondence: nowakmagdalena41@gmail.com (M.N.); marta_skorka@o2.pl (M.S.-M.); \\ wojciech.zwierello@gmail.com (W.Ż.) \\ + Presented at the 1st International Electronic Conference on Cancers: Exploiting Cancer Vulnerability by \\ Targeting the DNA Damage Response, 1-14 February 2021; Available online: https:/ /iecc2021.sciforum.net/.
}

check for updates

Citation: Nowak, M.; SkórkaMajewicz, M.; Żwierełło, W. Changes in Gene Expression of Metalloproteinases-2 and -9 and Their Inhibitors TIMP2 and TIMP3 in Human Glioma Cells Exposed to Low Levels of Fluoride. Med. Sci. Forum 2021, 3, 14. https://doi.org/10.3390/ IECC2021-09229

Academic Editors: Nicola Curtin and Helen E. Bryant

Published: 31 January 2021

Publisher's Note: MDPI stays neutral with regard to jurisdictional claims in published maps and institutional affiliations.

Copyright: (C) 2021 by the authors. Licensee MDPI, Basel, Switzerland. This article is an open access article distributed under the terms and conditions of the Creative Commons Attribution (CC BY) license (https:// creativecommons.org/licenses/by/ $4.0 /)$.
Abstract: Introduction: Fluorine compounds are common environmental pollutants and may excessively penetrate the human body, especially the brain (fluoride penetrates the blood-brain barrier). Some of the latest studies have shown that fluoride may interfere with some of the metabolic pathways involved in the development of invasive potential in many types of cancer (e.g., Wnt/catenin or NF- $\mathrm{kB}$ ). One of the stages of tumor invasion is the degradation of the extracellular matrix by metalloproteinases (MMP-2 and MMP-9), which allows for the migration and metastasis of cancer cells. Taking into account the above facts, we decided to check whether low concentrations of fluoride affect the expression level of genes encoding MMP-2 and MMP-9, as well as their TIMP-2 and TIMP-3 inhibitors, in human glioblastoma cells. Methods: U-87MG human glioblastoma cells were cultured with EMEM medium (10\% FBS, 2 mM glutamine, 1\% NEAA, $1 \mathrm{mM}$ sodium pyruvate, $100 \mathrm{IU} / \mathrm{mL}$ penicillin, $10 \mu \mathrm{g} / \mathrm{mL}$ streptomycin) under optimal conditions $\left(37^{\circ} \mathrm{C}\right.$ in an atmosphere of $5 \% \mathrm{CO}_{2}$ with $95 \%$ humidity). Cells were treated with sodium fluoride (NaF; $1-5 \mu \mathrm{M})$ for 24,48 , and $72 \mathrm{~h}$. The analysis of the expression level of the MMP-2, MMP-9, Timp-2, and Timp-3 genes was carried out via RT-PCR. Results: The results indicate that NaF $(0.1-5 \mu \mathrm{M})$ can disrupt the expression of MMP-2, MMP-9, Timp-2, and Timp-3. In the case of MMP-2, there was an approximately twofold increase in expression at $48 \mathrm{~h}(5 \mu \mathrm{M} \mathrm{NaF})$ and about a 2.5 -fold increase in expression at $72 \mathrm{~h}(0.1-5 \mu \mathrm{M} \mathrm{NaF})$. For MMP-9, an approximately threefold increase in expression was observed at $24 \mathrm{~h}(0.1 \mu \mathrm{M} \mathrm{NaF})$ and $48 \mathrm{~h}(5 \mu \mathrm{M}$ NaF). Both Timp-2 and Timp-3 showed a significant increase in expression observed at all time points, especially at the highest concentration of $\mathrm{NaF}(5 \mu \mathrm{M})$. Conclusions: The obtained results suggest that even low concentrations of fluorine compounds may have an undesirable influence promoting the invasive potential of human glioblastoma cells.

Keywords: glioblastoma; fluoride; metalloproteinases; invasion

Supplementary Materials: The poster presentation is available online at https: / /www.mdpi.com/ article/10.3390/IECC2021-09229/s1.

Funding: This study was performed with the use of funds granted by the Pomeranian Medical University in Szczecin.

Institutional Review Board Statement: Not applicable.

Informed Consent Statement: Not applicable. 